Papers and Proceedings of the Royal Society of Tasmania, Volume 118, 1984

(ms. received 1.III.1984)

\title{
THE GLACIAL DIVERSION OF THE QUE AND BULGOBAC RIVERS, WESTERN TASMANIA
}

by Eric A. Colhoun and Paul Augustinus

Department of Geography, University of Tasmania

(with one text-figure and one plate)

ABSTRACT

COLHOUN, E.A. and AUGUSTINUS, P., 1984 (31 viii): The glacial diversion of the Que and Bulgobac Rivers, western Tasmania. Pap. Proc. R. Soc. Tasm., 118: 1-4, pl.1. https://doi.org/10.26749/rstpp.118.1 ISSN 0080-4703. Department of Geography, University of Tasmania, Hobart, Tasmania, Australia.

Glacier ice diverted the courses of the upper Que and Bulgobac Rivers from a direct route to the Pieman River through the Que Gorge to the Huskisson River. The diversion probably occurred in the Early Pleistocene but the drainage pattern established was maintained and perhaps accentuated by further glaciation during the Middle Pleistocene. The modern drainage pattern is a palimpsest of that which existed by late Middle Pleistocene times.

\section{INTRODUCTION}

Repeated glaciation during the Quaternary had profound effects on the morphology of the West Coast Range of Tasmania. The small ice caps, with their reticulate pattern of outlet glaciers in the deep valleys west of the range, not only produced erosional and depositional glacial landforms but also modified the directions taken by some elements of the preglacial drainage systems. The most notable example is the diversion of the Que and Bulgobac Rivers from their former course via the Tramway and Farm creeks to the Pieman River through the Que Gorge to the Huskisson River. A similar diversion. of John Lynch Creek from the Marionoak to the Huskisson occurred at the head of the Marionoak River, and of the upper part of the Boco Creek from Tramway Creek to the present Boco Creek (figs 1A and $B$ ).

An example of glacial diversion of drainage has been described from Cradle Valley, where last glaciation ice caused a northeasterly flowing strike-aligned stream to be diverted northwards in a deep gorge across a ridge (Colhoun 1980). However, no diversion of drainage associated with pre-last glacial age ice has been described from Tasmania, although Reid (1918) considered that the flat plain of the Boco Valley marked a preglacial river course that commenced at the confluence of Farm Creek with the Pieman River and flowed northwards. Reid regarded this stream as having come from the Mackintosh Valley.

Recent investigations of the glacial geomorphology of the area between Bulgobac and the upper Pieman Valley suggests that the evolution of the modern drainage pattern (fig. 1A) from the reconstructed preglacial drainage pattern (fig. 1B) probably occurred as the result of diversion during at least two periods of glaciation (fig. 1C) that preceded the last glaciation. The probable sequence of events and drainage evolution is now interpreted with regard to the ice limits inferred from the glacial deposits.

\section{THE BOCO-BULGOBAC-QUE-MARIONOAK RIVER AREAS}

The relatively broad, predominantly flat-floored depression that extends northwards from the Pieman River and is occupied by Farm Creek in the south, Tramway and upper Boco creeks in the middle, and Animal and Bulgobac creeks in the north is separated from the middle section of the Que River by a low ridge at 520 to $560 \mathrm{~m}$ elevation. The surface of this depression descends southwards from 520 to $160 \mathrm{~m}$ in $15 \mathrm{~km}$. It is filled with thick glacial till and outwash deposits that overlie rhyolitic tuffs with intercalated sediments of the Cambrian Mount Read Volcanic Formation. To the east the depression is bounded by a 


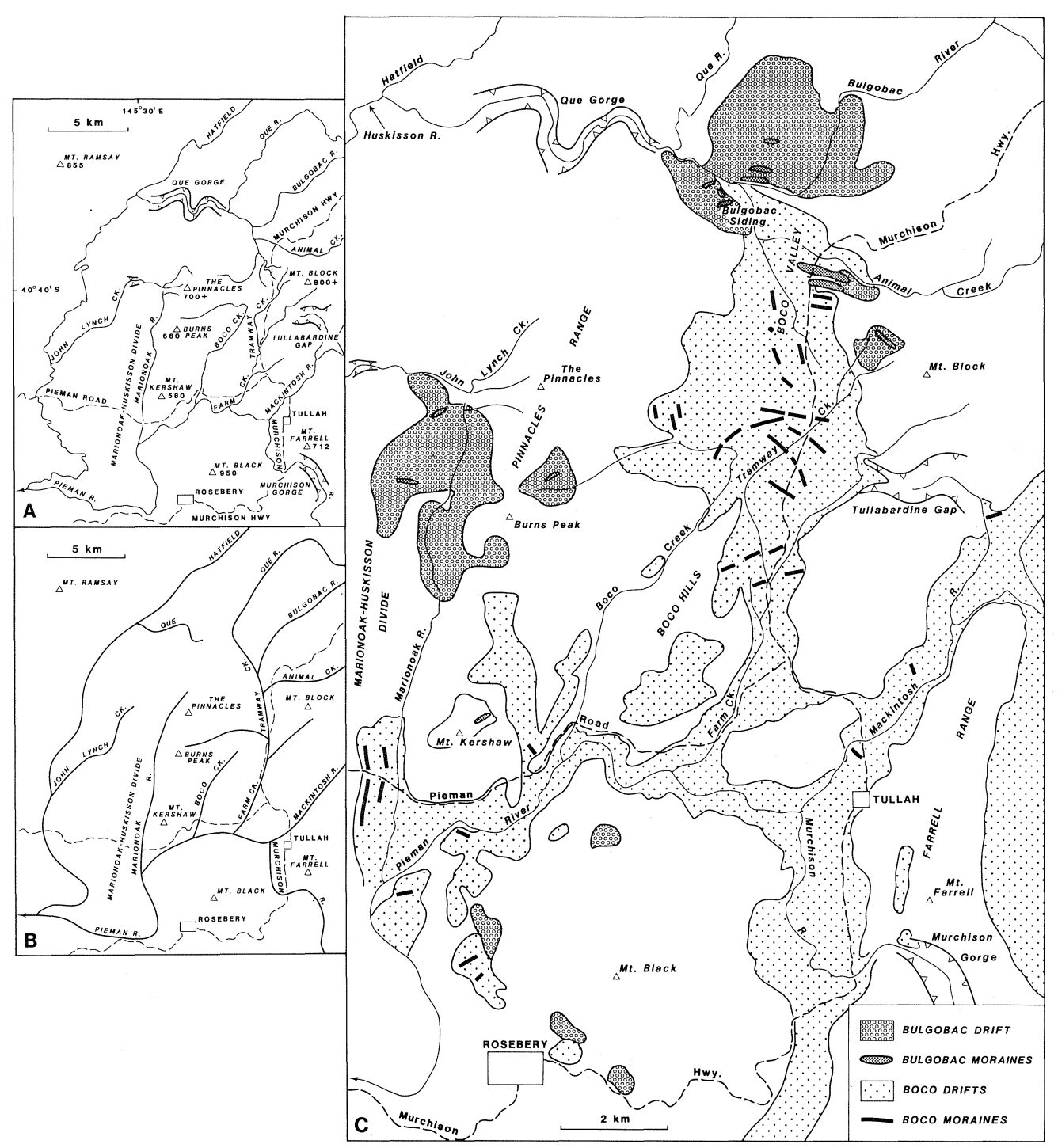

FIG. 1 - A: Modern drainage pattern of the Boco-Bulgobac-Que River region.

$B$ : Reconstructed probable preglacial drainage pattern.

C: Deposits of the Bulgobac and Boco Glaciations.

northeast strike-oriented ridge formed mainly of volcanics, the highest point of which is Mount Block $(800+\mathrm{m})$. The ridge is breached only by the 300 m-deep glacial diffluence of Tullabardine Gap. To the west the depression is bounded by the Pinnacles Fault, and the northeasterly trending strike-ridge that includes Burns Peak $(660 \mathrm{~m})$ and the Pinnacles 
Eric A. Colhoun and Paul Augustinus

$(700+m)$, which separate it from the Marionoak Valley. This ridge consists main1y of volcanic rocks.

The strongly trellissed drainage pattern dominated by the NE-SW strikeoriented subsequent streams, the southward descent of the rock floor of the Boco Depression as determined from drilling and resistivity surveys made by the Electrolytic Zinc Co., Rosebery, and the apparent1y young 80-200 m deep incised course of the Que Gorge (plate 1), indicates that the preglacial drainage of the area resembled that of figure 1B, and was tributary to the Pieman River. The preglacial Tramway-Farm creek system drained southwards rather than northwards as suggested by Reid. The preglacial age of this deep valley is indicated in bore holes, where up to $5 \mathrm{~m}$ of weathered volcanic bedrock has been encountered beneath the glacial drift. This indicates that a long period of subaerial weathering occurred prior to glacial deposition, and that the bedrock form of the valley was similar to present.

The Marionoak Valley and the ridge to the west that separates it from the Huskisson Valley are also formed predominantly of Cambrian volcanic rocks. The upper part of the John Lynch Creek drains southwestwards towards the head of the Marionoak River but at about $500 \mathrm{~m}$ elevation it turns abruptly westwards and drains through a small gorge into the Huskisson Valley leaving the upper part of the Marionoak beheaded. Similarly, a tributary that flowed eastwards towards

Tramway Creek from north of Burns Peak appears to have been diverted southwestwards along Boco Creek.

\section{GLACIATION AND DRAINAGE DIVERSION}

Field mapping of the glacial landforms and deposits by Augustinus in the area revealed the occurrence of at least two glaciations that preceded the last glaciation. The older glaciation, referred to as the Bulgobac, is represented by highly weathered till and outwash deposits that extend at least $3 \mathrm{~km}$ north of the Bulgobac River in the upper Boco valley. These deposits are up to $50 \mathrm{~m}$ thick and are bounded to the south by large morainic ridges that extend from Animal Creek to Bulgobac Siding (fig. 1C). Similar highly weathered till, outwash deposits, and small ridges of moraine occur in the upper part of the Marionoak Valley. Both suites were deposited by northward and northwestward moving ice from the Pieman Valley. The high degree of weathering, and the reversed magnetisation of laminated deposits associated with similar weathered glacial deposits recorded by Barbetti \& Colhoun from the Marionoak-Huskisson divide in the Pieman Valley, indicate that the glacial deposits are at least as old as the Early Pleistocene.

The initial diversion of the Que and Bulgobac rivers, and Animal Creek through the Que Gorge, and the diversion of the John Lynch Creek through its small gorge to the Huskisson River, occurred during the maximum extent of ice and the initial retreat stages of the Bulgobac Glaciation (fig. 1C). The form of the glacial deposits and their thick- 
ness in the Bulgobac and upper Marionoak valleys indicate that after the initial diversion the headwaters of the Que and Bulgobac rivers, Animal Creek, and John Lynch Creek were never again connected with their preglacial courses via Tramway and Farm Creeks, and the Marionoak River to the Pieman.

After a long interval, but prior to the last glaciation the Boco Valley was again glaciated by ice that flowed northwards from the Pieman and westwards through the Tullabardine Gap. This Boco Glaciation may have occurred as two stages, Boco I extending to Animal Creek and Boco II extending to Boco Railway Siding. The till and outwash deposits occur on the floor of most of the Boco Valley and in the Pieman Valley as far as the two moraines that occur $500 \mathrm{~m}$ west of the Marionoak River and adjacent to the Pieman Road. Ice of the Boco Glaciations did not extend to the upper part of the Marionoak Valley. There are numerous moraine ridges in the middle and upper Boco Valley. The ice that deposited these poured a great sheet of outwash gravels northwards towards the Bulgobac River and the intake to the Que Gorge (plate 1). This ice, and its deposits, which are up to $48 \mathrm{~m}$ thick near Boco Railway Siding and $1 \mathrm{~km}$ to the north (Electrolytic Zinc Co. drilling records), have maintained the diverted courses of Animal Creek and the Bulgobac River through the Que Gorge. Thick glacial gravels have diverted the tributary west of Tramway Creek southwestwards into the head of the Boco Creek, which occupies a former large meltwater channel. The deposits associated with the Boco Glaciations are beyond the range of ${ }^{14} \mathrm{C}$ assay, are moderately weathered, and appear to be of pre-last interglacial age. Therefore, it would appear that the pattern of glacial drainage that existed at the end of the Boco Glaciation (probably the penultimate glaciation) was the pattern inherited by the modern streams.

\section{CONCLUSION}

From the field evidence related to the extent of former glaciation it can be concluded that the Que and Bulgobac rivers, and Animal Creek were diverted westwards through the Que Gorge, and that John Lynch Creek was diverted westwards through a small gorge to the Huskisson River in the Early Pleistocene ( $>700000 \mathrm{yr}$ B.P.). The effects of the later Boco Glaciations were to maintain the diverted courses of these rivers. In addition, ice of the Boco Glaciation diverted the upper part of Tramway Creek through the Que River Gorge, and a western tributary into the head of Boco Creek during the Middle Pleistocene. There has been virtually no alteration of the drainage pattern that was formed by late middle Pleistocene times (pre 130000 yr B.P.) during the Late Pleistocene (post 130000 yr B.P.).

\section{REFERENCES}

Colhoun, E.A., 1980: Glacial diversion of drainage in the Cradle Mountain National Park, Tasmania. Austr. Geogr., 14 (6): 365-7.

Reid, A.M., 1918: The North Pieman, Huskisson and Stirling Valley Mining Fields.

BuzZ. Geol. Soc. Tasm., No.28. 